\title{
CORRESPONDENCE
}

\section{Induction of labour}

Sir Dugald Baird, FRCOG; D J Robson, MRCP; Ann Oakley, PHD; P W Howie, MRCoG,

and others.................. 896

Help for families of severely

handicapped children

E de H Lobo, MrCPED . . . . . . . . . . . . . . . . 897

International units and standards in immunology

J H Humphrey, FRCP, FRS, and I Batty . . . 898

Iron deficiency and restless legs

W B Matthews, FRCP................ 898

Specialties within community medicine

M D Warren, FRCP; F Alwyn Smith,

FRCPGLAS; D S Pickup, MFCM, and S G

Rubin, MFсM; D J Hewett, MB; Sheila A

Adam, MB, and others. . . . . . . . . 898

Constipation and soiling in childhood

I S Berg, MRCPSYCH..............900
Herpesvirus and cervical cancer

J K Oates, fRCPED...............900

Metabolic effects of bran

A R Leeds, MB, and others. . . . . . . . .900

Student counselling

S Crown, FRCP. . . . . . . . . . . . 901

Assessment of preoperative cases

W N Rollason, FFARCs. . . . . . . . . . . . 901

Spasmolytics for postoperative bowel

contractions

J W H Watt, MB..................901

High intestinal lactase in Pakistanis

G Y Zakaria, MB . . . . . . . . . . . . 901

Cervical diameter after suction

termination of pregnancy

M M Black, PHD, and B Alderman, MRCOG. . 902

\section{GMC election}

G Wiseman, MD...............902
Cover out of hours

M Dales, MrCGP..............902 Improving the hospital service?

P A Hill.........................902

Distinction awards

S Bourne, FRCPSYCH, and C P L Bruggen,

MRCPSYCH $\ldots \ldots \ldots \ldots \ldots \ldots \ldots \ldots \ldots \ldots 2$ RHA Or AHA ?

J R Spears, fFarcs. . . . . . . . . . . . . . . 903

Points from letters Progression and regression of atherosclerosis (A A Lewis); First aid in acute myocardial infarction (J B Irving); Pets in hospitals (D M Prinsley); After stroke, what? (E M Hollinrake); Induction of labour (F S Rickards); Rheumatic fever in Southern Africa (M Super); Departmental English (C M T Gleave); A buyer's market (W M Keynes); Vertebral artery occlusion and oral contraceptives (J C Gautier); Metrication Bill (V A

Goldman) .....................903
Correspondents are urged to write briefly so that readers may be offered as wide a selection of letters as possible. So many are being received that the omission of some is inevitable. Letters should be signed personally by all their authors.

\section{Induction of labour}

SIR,-I have read with interest your leading article (27 March, p 729) on the topical subject of induction of labour. You state that my work "provided the major impetus to the recent progressive increase in the practice" and that I claimed that the induction policy "was responsible for the dramatic decrease in perinatal mortality in Aberdeen in comparison with the rest of Scotland." I did not make such a claim and have never advocated wholesale induction in an effort to lower the perinatal mortality rate. You also think that it was unfortunate that "Baird never carried out the [controlled clinical trial] that would have proved his point." I hope the following short observations may help to clear up any misunderstanding.

In Aberdeen in 1946-7 22\% of all first births were to women of 30 years of age or more and many of these were delivered at home or in small maternity nursing homes. In these years $40 \%$ of all perinatal deaths in first births were due to either birth trauma or placental insufficiency. The pregnancy had lasted 42 weeks or more in $40 \%$ of the cases in both cause groups. In $1948-52$ over $90 \%$ of all first births took place in the central teaching hospital and the perinatal mortality rate from these two causes was 13 per 1000 compared

with 23 in 1946-7. The caesarean section rate increased from 1.7 to $2.8 \%$. All age groups benefited from the improved standard of care which was possible in a well-staffed teaching hospital. The accompanying table shows that the death rate from placental insufficiency was still very high in women aged 30 or over. Meanwhile our researches had shown that the oxygen saturation of the blood of the umbilical vein fell steadily with increasing age of the mother and increasing length of gestation beyond 40 weeks, suggesting that oxygen lack was the immediate cause of death from placenta insufficiency. It was impossible to identify the individuals who were at most risk, and since $25 \%$ of the deaths from placental insufficiency in 1948-52 occurred before the onset of labour and some early in labour the majority could not be prevented. The policy of induction, aimed at forestalling deaths, was determined by the epidemiological findings. The risks in women of 30 years of age or more were deemed too great to justify setting up a control group, especially since some of the women had been infertile for years.

The table shows that in 1953-7 a dramatic fall occurred in the death rate from placental insufficiency in those over the age of 30 . In the case of birth trauma the fall in the death

Perinatal mortality rates (per 1000) from placental insufficiency and birth trauma and caesarean section rates, first pregnancies, Aberdeen. Figures in parentheses refer to number of deaths or caesarean sections

\begin{tabular}{|c|c|c|c|c|c|}
\hline & \multirow{2}{*}{ Period } & \multicolumn{4}{|c|}{ Maternal age (years) } \\
\hline & & $<25$ & $25-29$ & $\geqslant 30$ & All ages \\
\hline Placental insufficiency & $\begin{array}{l}1948-52 \\
1953-7\end{array}$ & $\begin{array}{l}2.9(10) \\
2.6(9)\end{array}$ & $\begin{array}{l}7 \cdot 6(11) \\
5 \cdot 4(8)\end{array}$ & $\begin{array}{c}24.0(17) \\
5.4(3)\end{array}$ & $\begin{array}{l}6.8(38) \\
3.7(20)\end{array}$ \\
\hline Birth trauma & $\begin{array}{l}1948-52 \\
1953-7\end{array}$ & $\begin{array}{l}5 \cdot 8(20) \\
3.8(13)\end{array}$ & $\begin{array}{l}6 \cdot 2(9) \\
4 \cdot 7(7)\end{array}$ & $\begin{array}{l}8.4(6) \\
1.8(1)\end{array}$ & $\begin{array}{l}6 \cdot 2(35) \\
3.8(21)\end{array}$ \\
\hline Caesarean section & $\begin{array}{l}1948-52 \\
1953-7\end{array}$ & $\begin{array}{l}1 \cdot 1(27) \\
2 \cdot 3(72)\end{array}$ & $\begin{array}{l}1 \cdot 1(26) \\
5.9(75)\end{array}$ & $\begin{array}{l}13 \cdot 1(56) \\
16 \cdot 4(69)\end{array}$ & $\begin{array}{l}2 \cdot 8(115) \\
4 \cdot 4(212)\end{array}$ \\
\hline
\end{tabular}

rate was also greatest in the 30 -and-over age group. This might have been expected, since the incidence of long dysfunctional labour increases with increasing age of the mothe and with increasing postmaturity and this could explain the fall in the death rate with only a small increase in the caesarean section rate. In women under 30 years of age the caesarean section rate has increased, particularly in the 25-29 age group, but fewer operations were performed after a long trial of labour. The fall in the perinatal mortality rate in women under the age of 25 , who constituted the great majority and in whom induction was done only for recognised complications, gives further evidence that the overall fall in the perinatal mortality rate in first pregnancies was related basically to a general improvement in the management of pregnancy and labour. A control group against which to measure the effect of the induction policy was provided from the data of the national survey ${ }^{1}$ in 1958. The national perinatal mortality rate in first births in 1958 was $20 \%$ higher than the rate in Aberdeen in 1953-7 and $22 \%$ of the deaths in the survey occurred in pregnancies which had lasted 41 weeks or more compared with $11 \%$ in Aberdeen. In addition the perinatal mortality rate from placental insufficiency and birth trauma in primigravidae of $\mathbf{3 0}$ years of age or more was twice as high in the survey as in Aberdeen, probably related to the fact that the caesarean section rate in Aberdeen was almost twice the national average. Today primigravidae are taller, healthier, and younger than those of a generation ago and for this reason the dangers of prolonged pregnancy are less. Since only $5 \%$ of primigravidae today are 30 years of age or more the number who are at serious risk of prolonged pregnancy is now small.

Dugald Baird

MRC Medical Sociology Unit,

Medical Sociology,

Aberdeen

Perinatal Mortality: the First Report of the 1958 British Perinatal Mortality Survey under the Auspices of the National Birthday Trust Fund, ed N R Butle stone, 1963 . 